\title{
METHODICAL ASPECTS OF SOIL ECOSYSTEM SERVICES VALUATION
}

Agnieszka E Latawiec $^{\text {a,b,c,d,e* }}$, Aline Rodrigues ${ }^{\mathrm{a}, \mathrm{b}}$, Katarzyna A Korys ${ }^{\mathrm{b}, \mathrm{e},}$, Bruna Medeiros ${ }^{\mathrm{b}, \mathrm{f}}$

a Department of Geography and Environment - Rio Conservation and Sustainability Science Centre, Pontifical Catholic University of Rio de Janeiro, R. Marquês de São Vicente, 225, Gávea, Rio de Janeiro, 22451-000, Brazil, e-mail: a.latawiec@iis-rio.org ORCID 0000-0003-3036-1870 e-mail: a.rodrigues@iis-rio.org; ORCID 0000-0003-3231-551X

b International Institute for Sustainability, R. Dona Castorina 124, Jardim Botânico, Rio de Janeiro, 22460-320, Brazil, e-mail: k.korys@iis-rio.org ORCID 0000-0002-4301-2146, e-mail: b.medeiros@iis-rio.org; ORCID 0000-00028830-0053

c Department of Production Engineering, Logistics and Applied Computer Science, Faculty of Production and Power Engineering, University of Agriculture in Kraków, Balicka 116b, 30-149 Kraków, Poland

d School of Environmental Sciences, University of East Anglia, Norwich Research Park, Norwich NR4 7TJ, UK

e International Institute for Ecology and Sustainable Development (IIS Poland Fund), Tęczowa 17/8, Opole 45-759, Poland

f Department of Ecology, Post Graduate Program in Ecology, Federal University of Rio de Janeiro, Rio de Janeiro, 21941-971, Brazil

${ }^{*}$ Corresponding author: e-mail: a.latawiec@iis-rio.org

\begin{tabular}{|c|c|}
\hline ARTICLE INFO & ABSTRACT \\
\hline $\begin{array}{l}\text { Article history: } \\
\text { Received: December } 2021 \\
\text { Received in the revised form: } \\
\text { January } 2022 \\
\text { Accepted: February } 2022 \\
\text { Keywords: } \\
\text { agricultural systems, } \\
\text { biochar, } \\
\text { methods, } \\
\text { frameworks }\end{array}$ & $\begin{array}{l}\text { Ecosystem Services Valuation is an important tool for dialogue in the } \\
\text { decision-making process and to highlight the society's dependence on } \\
\text { the biosphere for well-being. Soil is the primary source of ecosystem } \\
\text { services such as the production of food and regulating the climate, how- } \\
\text { ever the methodological alternatives for valuing soil ecosystem services } \\
\text { remain poorly studied. The aim of this paper is to demonstrate method- } \\
\text { ical aspects of ecosystem services valuation, with the special attention } \\
\text { to soil services within agricultural context. We introduce frameworks } \\
\text { specific for soil ecosystem services. Then, we present a case study } \\
\text { where soil ecosystem services were evaluated within agricultural con- } \\
\text { text. We conclude that such valuation represents the newest trend in } \\
\text { soil science wherein soil resources are treated in the wider context of } \\
\text { impacts on human well-being. }\end{array}$ \\
\hline
\end{tabular}

\section{Introduction}

\section{Ecosystem services overview}

Ecosystem services (ES) can be defined as all the benefits human beings obtain from ecosystems and as a policy tool to achieve the sustainable use of natural resources. ES have 
been receiving increasing attention since the publication of the Millennium Ecosystem Assessment report (MEA, 2005). MEA divides ecosystem services into four categories: (i) provisioning services (direct or indirect food for humans, freshwater, wood, fiber, and fuel); (ii) regulating services (regulation of gas and water, climate, floods, erosion, biological processes such as pollination and diseases); (iii) cultural services (esthetic, spiritual, educational and recreational); and (iv) supporting services (nutrient cycling, production, habitat, biodiversity); (MEA 2005). However, MEA did not provide a fully functional concept to assist policymakers and provide sufficient economic tools to value ES and natural resources (Armsworth et al., 2007; Seppelt et al., 2011).

The ecosystem approach is a well-established strategy for the integrated management of water, land, and living resources that fairly promotes conservation and sustainable use (Beaumont et al., 2017). Ingram et al. (2014) presents the detailed classifications of the ES approach. It was found that one of the most used and cited approaches is the Payment for Ecosystem Services (PES) as a form of ES valuation. Other approaches include measuring, modelling and / or mapping the resources and flows of different ES and the synergies and / or trade-offs that may occur between them because of various decisions, and the identification and quantification of the social, cultural and / or economic value of ES (Ingram et al., 2014).

Conceptual advances were proposed for The Economics of Ecosystems and Biodiversity (TEEB) project (Balmford et al., 2008). TEEB encouraged identifying the wide range of ecosystem and landscape benefits, using economic tools and methods to make the services economically visible, and incorporating ecosystem and biodiversity benefits into decision-making through incentives and price signals (Sukhdev et al., 2014). These advances were used for the review of ES in Europe as well as provided detailed suggestions for enabling economic valuation of ES (Fisher et al., 2008).

The Intergovernmental science-policy platform on biodiversity and ES (IPBES) in 2015 published its classification system (Diaz et al., 2015). One of the main contributions of the IPBES was to show the existence of a different understanding of nature and its benefits by different cultures. Consequently, value systems will also be different, which vary between individuals within a group and between groups at various temporal and spatial scales. The IPBES highlights three types of value: the non-anthropocentric (intrinsic) and the anthropocentric (instrumental and relational). Instrumental value can be defined as a value attributed to something like a means to a specific end. The relational value corresponds to the value between individuals and society, individuals with non-human nature, and individuals with other different aspects of the world. On the other hand, the intrinsic value corresponds to the inherent value, which is the value that something has regardless of human evaluation (Pascual et al., 2017). The IPBES framework is focused on advancing a common understanding that improves communication between different disciplines, knowledge systems and stakeholders. The objective of this paper is to discuss the approaches of ES valuation to soil services in agricultural context through demonstration of frameworks specifics for soil ES and case studies in agricultural context of Germany, Poland and UK.

\section{Types of valuation of ecosystem services}

The valuation of ES is frequently related to the two main concepts: ecological valuation, with calculations based on biological and physical aspects (e.g. thermodynamic principles 
and exchange between energy and matter in physical environment) and economic valuation, based on the consumer preferences (e.g. measurement of individual preferences about the quality or quantity of a natural resource, which is converted to measures of well-being) (Spangenberg and Settele, 2010; Maes et al., 2018).

Regarding the economic aspect, the valuation of ES assesses the economic value of the ES through an equivalence comparison with other resources available in the economy (Costanza and Daly, 1992; Costanza et al., 1997; Spangenberg and Settele, 2010). Economic terminology is a path of dialogue that aims to bring scientific evidence closer to decision-making processes (Bingham et al., 1995; de Groot, 1992). Then, it is possible to account for ES considering aspects such as productivity, efficiency and natural capital (Costanza et al., 1997). Vegh et al. (2014) organized methodological approaches of ecosystem services valuation in categories: Market-Based Valuation (MV), Non-Market Valuation (NMV) and Synthesis of Existing Studies (SES).

MV considers the price or exchange value of a service on the open market and can be estimated by methods such as: (a) Market Value, in which is accounted an ecosystem service or product through your value of sold or bought in the market; (b) Substitute Price, Replacement Cost, Avoided Cost, Avoided Damages, in which is calculated the value to replacing ES, supply an ES substitute or cover the costs related to the loss of a SE and/or its damages associated; (c) Change in Productivity, Net Factor Income, in which is obtained the values of ecosystem products or services commercialized as market goods.

NMV includes methods of ES valuation which is not possible to determine real (directly or indirectly) or hypothetical market prices. This category considers the non-market goods (e.g. insurance goods, public value goods) and comprises (a) Stated Preferences and (b) Revealed Preferences. On the Stated Preferences, hypothetical markets of a respective SE are created in which people interviewed need to set a price for this ecosystem service. The main methods are Contingent Valuation (in this case, a target group reveals the willingness to pay and/or willingness to accept a hypothetical scenario) and Choice Modelling (target group needs to choose the best price among different sets of alternatives - in which price is one parameter among others). On the Revealed Preferences, indirect calculations are performed from the effects of behavioral change associated with a service or its absence in the real market. Values of existence, non-consumptive use values and consumptive use values are considered in this approach. Travel Cost, one of the most applied Revealed Preference, consists of attributing the value of an ecosystem or site used for recreation through the amount paid for its enjoyment.

SES comprises the efforts to gather information through existing literature. In this category are considered methods such as Meta Analysis (estimation of statistically robust patterns on the combination of a set of data from different sources); Benefit Transfer (economic value and its benefits are estimated from displacement of value of another location); Citation (direct citation of the results of a study); Ecosystem Value Coefficient (estimation of ES values through multiplication the area by value coefficients according to the type of land use and based on global averages). 
A. E. Latawiec, A. Rodrigues, K. A. Korys, B. Medeiros

\section{Developing a Country-Specific Approach on ES - Case Study from Germany, Poland and UK}

At the local scale, an analytical framework for the conceptualization and quantification of the interactions between ES provisioning was applied in the Leipzig-Halle urban region in eastern Germany (Haase et al., 2012). The framework was based on assessing the change in the timing of ecosystem services depending on the change in land cover and proposed to use aggregate values for the entire urban region, functional zones and spatially separate raster transformed maps. The analysis showed a loss in the ecosystem services' provisions because of soil sealing in the peri-urban areas; however, it showed the synergies of ecosystem services resulting from brownfield-transition into green space and mining restoration. The study showed that trade-offs and synergies between ecosystem services are not stable relationships and that they might change over short periods of time depending on the change in land cover. At a more general level, the results of the case study showed that the assessment of ecosystem services' provisions succeeds at different scales and delivers consistent results. Because the framework involves a zone-by-zone assessment, the growth and shrinkage processes in the urban and peri-urban parts of a region can easily be analyzed. Using the spatial map approach, it is possible to identify and localize areas of change in ecosystem services provisioning synergies and trade-offs.

Among other European countries, Poland is an interesting case for the analysis of environmental policies at the national level (Mączka, 2019). The fall of communism in 1989 and the accession to the EU in 2004 had a significant impact on the Polish system of environmental protection (Kluvánková-Oravská et al., 2009). The reforming of environmental policy changed (Grodzinska-Jurczak and Cent, 2011), including the wider participation of stakeholders and the emergence of new concepts emerged, including ES (Mączka, 2019). Subsequent studies have shown that the use of the ES approach in Poland is increasing, however the knowledge on the practical way of using this approach is still in scarce (Stępniewska et al. 2018). The first conceptual framework for the valuation of ES for Poland was proposed in 2012 by Mizgajski and Stępniewska. It was based on the recommendations of the European Environment Agency (EEA) with the use of the existing sources of qualitative and quantitative data and adapting the experiences of advanced countries in this field. For ES valuation, geographic regionalization was used as the basis for spatial differentiation of the structure of ecosystems in Poland. The authors proposed the separation of seven landscape and ecological zones (the Baltic Sea with a coastal zone, Lakeland, Lowlands, Uplands, Piedmont Valley, Middle High Mountains and Alpine Mountains), which correspond to the principle of socioecological landscape units (SELU) through the EEA. In addition, using the Corine Land Cover 2006 (CLC) spatial database, they proposed to create seven types of land cover: urban areas, agricultural land, meadows, forests, rivers and lakes, the Baltic Sea, others, which correspond to the functional units of land cover (LCFU) according to EEA. The presented approach aimed to enable the assessment of ecosystem services in Poland from the perspective of aggregated forms of land use, considering the specificity of the ecological units and the main landscape (Mizgajski and Stępniewska 2012). In turn, framework for ES developed by Mączka et al. (2019) has been identified as an important communication tool for different stakeholder groups (e.g., NGOs, farmers, the private sector, etc.) to discuss the future management of Natura 2000 sites in Poland. The authors claimed that the presented ES framework can serve as a descriptive overview of management challenges and can also provide 
Methodical aspects...

a space for prescriptive statements that deserve attention in public forums and minimize conflicts over the future of protected areas in Poland. In addition, the authors emphasize that to better understand and manage complex systems involving biological and human societies, there is a strong need to develop communication tools that will enable collaboration between multiple stakeholders and researchers from different fields of science (Mączka et al. 2019).

The UK National Ecosystem Assessment (UK NEA) proposes a framework based on existing methods, especially those used for the MEA (MEA 2005). In the UK NEA, ecosystem services are considered under the broad headings of provisioning, supporting, regulating and cultural services. This classification derives from the MEA (2005) and is a useful means for distinguishing broad categories of services. 'Final ecosystem services' directly contribute to the $\operatorname{good}(\mathrm{s})$ that are valued by people, and people tend to intervene or manage ecosystems to influence the delivery of final ecosystem services. Intermediate ecosystem services and 'ecosystem processes' underpin the final ecosystem services, but are not directly linked to good(s) and are less often the focus for management. In fact, ecosystem processes are often inadvertently affected by management for final ecosystem services, sometimes with deleterious consequences. The goods that are derived from final ecosystem services have a value, only some of which is derived from ecosystems because of capital inputs (from manufacturing and remanufacturing) that add value. Different goods will have different proportions of value attributable to ecosystems versus human capital inputs. The separation between ecosystem processes/intermediate services and final ES is necessary to avoid double counting when valuing the benefits derived from ecosystems (Fisher et al., 2008). It should be noted that provisioning and cultural services are always classed as final ES; regulating services may be either final services or intermediate services/processes; and supporting services are always intermediate services/processes. The provisioning, regulating, cultural and supporting services classification maps on to the MEA classification which is already in general use. UK NEA develops the distinction between final ES and intermediate ES and/or processes in order to allow the valuation of final ES.

\section{Soil ecosystem services}

Although soil is a fundamental resource for human well-being, soil ecosystem services, such as carbon sequestration and water regulation remain overlooked and poorly understood. Adequate valuation of soil ecosystem services is largely excluded from environmental impact assessments and rarely included into environmental policies. Below are a few examples of frameworks for valuation and their implications for soil management.

By merging the categories of soil functions defined by the Soil Thematic Strategy of the Swiss Office Federal of the Environment (FOEN) and the Thematic Strategy for Soil Protection (CEC, 2006), National Research Programme NRP 68 - Swiss National Science Foundation focuses on the following six soil function categories: (1) regulating functions such as functions regulating water, acting as a carbon sink, filtering and binding heavy metals, contaminants, and acids, (2) production functions such as agricultural production, timber production, and drinking water, (3) habitat functions such as habitat providing for microorganisms and plants, (4) archive functions such as the capacity to conserve geological and archaeological heritage, (5) engineering functions such as the physical and cultural environment for humans and human activities and (6) soil as source of raw materials. While soils 
managed in a sustainable manner can perform their regulating, production, and habitat functions in the long-term, engineering and resource functions are destroyed as soon as humans use soils for these services. This distinction is emphasized by classifying the latter two functions into "use functions", and the regulating, production and habitat functions into "ecological functions". There are as well different classification systems for ES. Soil "use functions" are linked to their services by adding the categories engineering, archive, and resource services. FOEN defines FEGS as goods or services that are provided by nature directly and are consumed by humans or used to produce market goods. The term FEGS allows thus to avoid double counting of services, making a clear distinction, between services contributing to ES and services directly generating wellbeing or directly contributing to the production of a good or a service. Soils, on the one hand, can provide a service directly, such as for example carbon sequestration, or, on the other hand, they can contribute to ES, for example as intermediate services in terms of water filtering and/or water storage for the final service of agricultural production. Agricultural production is thus the final ES, which not only depends on the supporting (soil) services but also on suitable climatic conditions, crop choice, fertilization, pest management as well as on the socio-economic context in which production takes place.

Dominati et al. (2010) recognized that a combined natural capital and ES approach is needed for soils. Focusing solely on final goods and services can lead to a problem analogous to that of using GDP as a welfare indicator: since GDP measures only flows, it tells one nothing of the sustainability of resource use, or what resource remains. Similarly, focusing only on final goods and services, tells little about the state of the ecosystem service delivery mechanisms.

Intergovernmental Platform on Biodiversity and Ecosystem Services (IPBES) assessment is focused on land and soil is expressively targeted in the scoping document of the IPBES. It appreciates the importance to improve soil knowledge, including indigenous and local knowledge. A fundamental change is a shift towards treating soil as supporting service in relation to soil formation rather that providing, as soil itself is not used for human well-being rather it composes foundation for all other ES. As soil degradation is connected to land degradation, it details 11 forms of degradation: soil erosion, contamination, compaction, sealing, and sedimentation, loss of organic matter, soil and water salinization, degradation of freshwater systems, invasion of alien species, changes in natural fire regimes and pollution as a land degradation process. These threats are more or less equivalent to the list established in 2006 in the Proposal of a soil framework directive of the European Union that was abandoned in 2014. Moreover, soils serve as an illustration on the Chapter three on direct and indirect drivers of LDR: "Direct drivers of degradation (e.g., unsustainable levels of biomass extraction and extractive industries) can result directly in degraded land, including reduction in the productivity of land, or in processes such as soil erosion due to unsustainable land management techniques, and natural drivers, such as floods, wind and drought, that result in land degradation". Consequently, soils are an element of the IPBES process, which contributes to the global recognition that soil knowledge must be part of the assessment and we can expect that under the cover of land, soil issues will be indirectly addressed, especially by the Chapter 6 that deals with the identification of responses to avoid land degradation and restore degraded land and by the Chapter two about "Concepts and perceptions of LDR" (Desrousseaux et al., 2017).

Recognizing the importance of soils in the provision of ES and inspired by previously published studies, a recent study published a framework focused on soils (Rodrigues et al., 
2021). This study reinforces the importance of research, projects and institutions to recognize well the definitions of the SES concept and other associated concepts such as soil properties, processes and functions. Soil functions are understood as benefits to human and non-human nature, while soil services are benefits directed to human. Soil properties are directly measurable and express chemical, physical and biological characteristics. Soil processes are defined as transforming inputs into products, such as the decomposition of organic matter to form humus. In addition, the study emphasizes a large knowledge gap regarding the approach to SES in the tropical region.

In a recent paper, Latawiec et al. (2021) evaluated provisioning (food and feed) and regulating (carbon sequestration) soil ecosystem services from biochar use in soybean farming (Figure 1). Among different biochar doses, $60 \mathrm{Mg} \mathrm{ha}^{-1}$ was the most effective one for increasing soybean yields over two years and for two different biochars with additional benefits for water retention. However, the cost of biochar exceeded the potential financial benefits from the yield increase as compared to traditional fertilizer. Carbon sequestration was evaluated based on direct carbon savings in soil following biochar addition. Based on the dose of biochar, the proportion of fixed carbon in biochar (approx. 80\%) and the fraction of persistent biochar (70\%) Latawiec et al. (2021) calculated financial benefits to farmers from carbon sequestration in soil given three levels of subsidies for tonne of $\mathrm{CO}_{2}$ eq stored (USD 10, USD 20 and USD 30). They found that if with the subsidy of USD $30 \mathrm{t} \mathrm{ha}^{-1}$ from carbon sequestration, the soybean production with the addition of biochar $\left(40 \mathrm{Mg} \mathrm{ha}^{-1}\right.$ and $\left.60 \mathrm{Mg} \mathrm{ha}^{-1}\right)$ would be profitable already in the first year of cultivation. Interestingly, the carbon price would have to be in the range of USD 50 to USD 100 in 2030 to achieve the goals of the Paris Agreement.
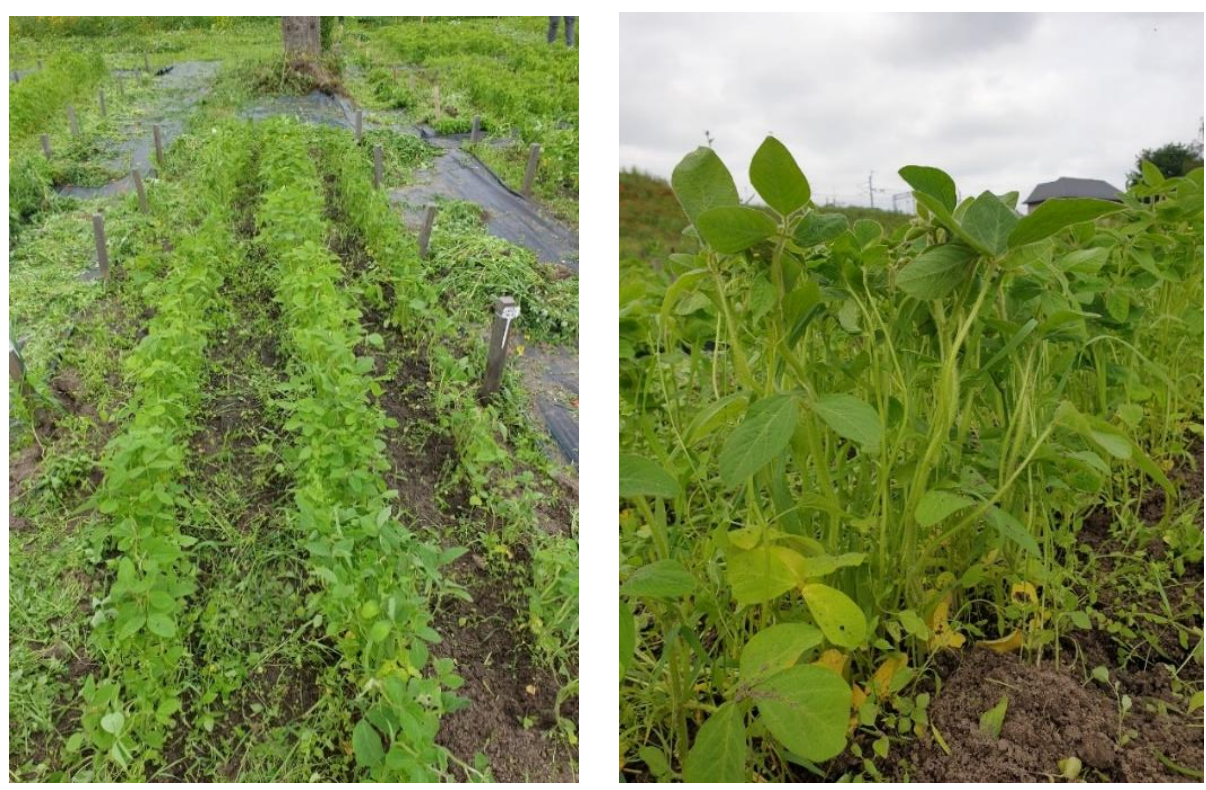

Figure 1. Evaluating biochar impact on soybean yields and other soil ecosystem services in Krakow, Poland. Photo by Maciej Kubon. 
Similarly, Latawiec et al. (2019) calculated food provision (from the additional potential beef production) and carbon sequestration based on the experiment with forage grasses in Brazil (Brachiaria spp. and Panicum spp.) (Figure 2). The highest additional meat production and profit was observed for the treatment with biochar (between US\$ 191 and US\$ 324 ha ${ }^{1}$ ), followed by the combination of fertilizer with inoculant. Also, each hectare amended with biochar saved 91 tonnes of $\mathrm{CO}_{2} \mathrm{e}$ through land sparing effect and 13 tonnes of $\mathrm{CO}_{2} \mathrm{e}$ sequestered in the soil, which could equal to U\$ 455 in carbon payments.
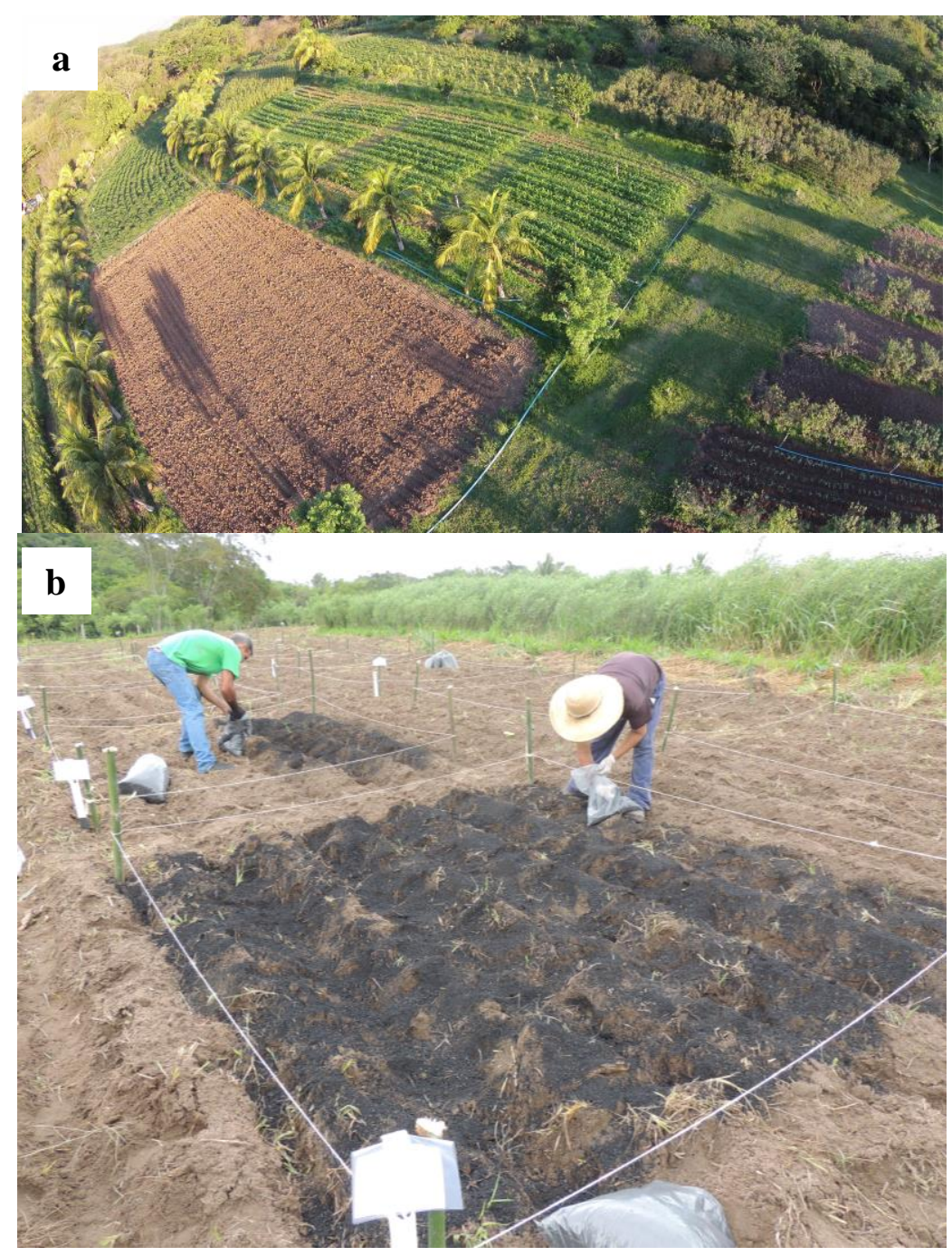

Figure 2a. Experimental field in Embrapa Agrobiology, Brazil where the experiment on soil ecosystem services from forage grasses production was conducted. Photo by VisionDrones. Figure 2b. Incorporating biochar into soil. Photo by Agnieszka Latawiec. 


\section{Conclusions}

1. Soil is an important natural resource that provides a range of ecosystem services, ensuring human well-being and sustainable socio-economic development. Nevertheless, some soil ecosystem services, such as carbon sequestration and water regulation, are overlooked and poorly understood, while services directly related to the provision of food are described in more detail in the scientific literature.

2. Since decision-making is based on indicators that provide concise and relevant information, valuing ecosystem services indicators can help identify gaps that helps policymakers adopting a more comprehensive approach to ecosystem services.

3. The valuation of soil ecosystem services represents the latest trend in soil science, where soil resources are viewed in the broader context of their impact on human well-being.

\section{Acknowledgements}

This research was financially supported by the Polish National Centre for Research and Development in the framework of 'Environment, agriculture and forestry'-BIOSTRATEG strategic R\&D programme, grant no. BIOSTRATEG3/345940/7/NCBR/2017 ('Water in soil-satellite monitoring and improving the retention using biochar'). Magdalena Markowicz is gratefully acknowledged for their help with manuscript formatting.

Financed from the subsidy of the Ministry of Education and Science for the Hugo Kołłątaj Agricultural University in Kraków for the year 2022.

\section{References}

Armsworth, P.R., Chan, K.M., Daily, G.C., Ehrlich, P.R., Kremen, C., Ricketts, T.H., Sanjayan, M.A. (2007). Ecosystem-service science and the way forward for conservation. Conservation Biology, 21(6),1383-4.

Balmford, A., Rodrigues, A.S.L., Walpole, M., ten Brink, P., Kettunen, M., Braat, L., de Groot, R. (2008). The Economics of Biodiversity and Ecosystems: Scoping the Science. Cambridge, UK: European Commission (ENV/070307/2007/486089/ETU/B2).

Beaumont, N.J., Mongruel, R., Hooper, T. (2017). Practical application of the Ecosystem Service Approach (ESA): lessons learned and recommendations for the future. International Journal of Biodiversity Science, Ecosystem Services \& Management, 13, 68-78.

Bingham, G., Bishop, R., Brody, M., Bromley, D., Clark, E.T., Cooper, W., Costanza, R., Hale, T., Hayden, G., Kellert, S., Norgaard, R., Norton, B., Payne, J., Russell, C., Suter. G. (1995). Issues in ecosystem valuation: improving information for decision making. Ecological Economics, 14, 73-90.

CEC, (2006). Commission Staff Working Document. Document Accompanying the Communication from the Commission to the Council, the European Parliament, the European Economic and Social Committee and the Committee of the Regions - Thematic Strategy for Soil Protection. Impact Assessment of the Thematic Strategy for Soil Protection. Brussels: SEC. Retrieved January 18, 2022, from https://eur-lex.europa.eu/legal-content/EN/TXT/?uri=celex:52006SC0620

Costanza, R., d'Arge, R., de Groot, R., Farber, S., Grasso, M., Hannon, B., Limburg, K., Naeem, S., O'Neill, R.V., Paruelo, J., Raskin, R.G., Sutton. P., van den Belt, M. (1997). The value of the world's ecosystem services and natural capital. Nature, 387, 253-260. 
Costanza, R., Daly, H.E. (1992). Natural capital and sustainable development. Conservation Biology, $6,37-46$.

de Groot, R. S. (1992). Functions of Nature: Evaluation of Nature in Environmental Planning, Management, and Decision Making. Wolters-Noordhoff, Groningen. Polar Record, 29(169), 162

Desrousseaux, M., Kotiaho, J.S., Kohler, F. (2017). Are Soils Taken into Consideration by the IPBES Assessment on Land Degradation and Restoration? In: Ginzky H., Heuser I., Qin T., Ruppel O., Wegerdt P. (eds) International Yearbook of Soil Law and Policy 2016. International Yearbook of Soil Law and Policy, 2016. Springer, Cham, 165-177.

Diaz, S., Demisse, S., Carabias, J., Joly, C., Lonsdale, M., Ash, N., Larigauderie, A., Adhikari, J.R., Arico, S., Baldi, A., Bartuska, A., Baste, I.A., Bilgin, A., Brondizio, E., Chan, K.M., Figueroa, V.E., Duraiappah, A., Fischer, M., Zlatanova, D. (2015). The IPBES Conceptual Framework connecting nature and people. Current Opinion in Environmental Sustainability, 14, 1-16.

Dominati, E., Patterson, M., Mackay, A. (2010). A framework for classifying and quantifying the natural capital and ecosystem services of soils. Ecological Economics, 69(9), 1858-1868.

Fisher, B., Turner, K., Zysitra, M., Brouwer, R., de Groot, R., Farber, S., Ferraro, P., Green, R., Hadley, D., Harlow, J., Jefferiss, P., Kirkby, C., Morling, P., Mowatt, S., Naidoo, R., Paavola, J., Strassburg, B., Yu, D., Balmford, A. (2008). Ecosystem services and economic theory: integration for policy-relevant research. Ecological Applications, 18(8), 2050-2067.

Grodzinska-Jurczak, M., Cent, J. (2011). Expansion of Nature Conservation Areas: Problems with Natura 2000 Implementation in Poland? Environmental Management, 47, 11-27.

Haase, D., Schwarz, N., Strohbach, M., Kroll, F., Seppelt, R. (2012). Synergies, trade-offs, and losses of ecosystem services in urban regions: an integrated multiscale framework applied to the Leipzig-Halle region, Germany. Ecology and Society, 17(3), 22.

Ingram, J.C., Wilkie, D., Clements, T., McNab, R.B., Nelson, F., Baur, E.H., Sachedina, H.T., Peterson, D.D., Foley, C.A.H. (2014). Evidence of Payments for Ecosystem Services as a mechanism for supporting biodiversity conservation and rural livelihoods. Ecosystem Services, 7, 10-21.

Kluvánková-Oravská, T., Chobotová, V., Banaszak, I., Slavikova, L., Trifunovova, S. (2009). From government to governance for biodiversity: the perspective of central and Eastern European transition countries. Environmental Policy and Governance, 19, 186-196.

Latawiec AE, Koryś A, Koryś KA, Kuboń M, Sadowska U, Gliniak M, Sikora J, Drosik A, Niemiec M, Klimek-Kopyra A, Sporysz M, Usowicz B, Medeiros B. (2021). Economic Analysis of Biochar Use in Soybean Production in Poland. Agronomy, 11, 2108.

Latawiec, A.E., Strassburg, B.B.N, Junqueira, A.B., Araujo, E., de Moraes, L.F.D., Pinto, H.A.N., Castro, A., Rangel, M., Malaguti, G.A., Rodrigues A.F., Barioni, L.G., Novotny, E.H., Cornelissen, G., Mendes, M., Batista, N., Guerra, J.G., Zonta, E., Jakovac, C., Hale, S.E. (2019). Biochar amendment improves degraded pasturelands in Brazil: environmental and cost-benefit analysis. Scientific Reports, 9, 11993.

Maes, J., Burkhard, B., Geneletti, D. (2018). Ecosystem services are inclusive and deliver multiple values. A comment on the concept of nature's contributions to people. One Ecosystem, 3, e24720.

Mączka, K. 2019. Ecosystem services in environmental discourse - Application of ecosystem services concept in Poland (in Polish: Usługi ekosystemowe w dyskursie środowiskowym. Studium wdrożenia koncepcji usług ekosystemowych w Polsce). Doctoral dissertation, University of Adam Mickiewicz in Poznań, Faculty of Social Sciences, Poland.

Mączka, K., Chmielewski, P., Jeran, A., Matczak, P., van Riper, C.J. (2019). The ecosystem services concept as a tool for public participation in management of Poland's Natura 2000 network. Ecosystem Services, 35, 173-183.

MEA, 2005. Ecosystems and Human Well-being: Synthesis. Washington, DC: Island Press. ISBN 159726-040-1.

Mizgajski, A., Stępniewska, M. (2012). Ecosystem Services Assessment for Poland - Challenges and Possible Solutions (in Polish: Ocena świadczeń ekosystemów dla Polski wyzwania i możliwe rozwiązania). Economics and Environment, 2(42), 54-73. 
Pascual, U., Balvanera, P., Díaz, S., Pataki, G., Roth, E., Stenseke, M., Watson, R.T., Dessane, E.B., Islar, M., Kelemen, E., Maris, V., Quaas, M., Subramanian, S., Wittmer, H., Adlan, A., Ahn, S., Al-Hafedh, Y., Amankwah, E., Asah, S., Berry, P., Bilgin, A., Breslow, S., Bullock, C., Caceres, D., Daly-Hassen, H., Figueroa, E., Golden, C., Gómez-Baggethun, E., Gonzalez-Jimenez, D., Houdet, J., Keune, H., Kumar, R., Ma, K., May, P., Mead, A., O'Farrell, P., Pandit, R., Pengue, W., Pichis-Madruga, R., Popa, F., Preston, S., Pacheco-Balanza, D., Saarikoski, H., Strassburg, B., van den Belt, M., Verma, M., Wickson, F., Yagi, N. (2017). Valuing nature's contributions to people: The IPBES approach. Current Opinion in Environmental Sustainability, 26-27, 7-16.

Rodrigues, A.F., Latawiec, A.E., Reid, B.J., Solorzano, A., Schuler, A.E., Lacerda, C., Fidalgo, E.C.C., Scarano, F.R., Tubenchlak, F., Pena, I., Vicente-Vicente, J.L., Korys, K.A., Cooper, M., Fernandes, N.F., Prado, R.B., Maioli, V., Dib, V., Teixeira W.G. (2021). Systematic review of soil ecosystem services in tropical regions. Royal Society Open Science, 8, 201584.

Seppelt, R., Dormann, C.F., Eppink, F.V., Lautenbach, S., Schmidt, S. (2011). A quantitative review of ecosystem service studies: approaches, shortcomings and the road ahead. Journal of Applied Ecology, 48, 630-636.

Spangenberg, J.H., Settele, J. 2010. Precisely incorrect? Monetising the value of ecosystem services. Ecological Complexity, 7, 327-337.

Stępniewska, M., Lupa, P., Mizgajski, A. (2018). Drivers of the ecosystem services approach in Poland and perception by practitioners. Ecosystem Services, 33(A), 59-67.

Sukhdev, P., Wittmer, H., Miller, D., 'The Economics of Ecosystems and Biodiversity (TEEB): Challenges and Responses', Helm, D., Hepburn, C. (eds) (2014). Nature in the Balance: The Economics of Biodiversity. Oxford: Oxford University Press.

Vegh, T., Jungwiwattanaporn, M., Pendleton, L., Murray, B. (2014). Mangrove ecosystem services valuation: state of the literature. Durham, NC: Duke University. (NI WP 14-06).

\section{METODYCZNE ASPEKTY WYCENY USEUG EKOSYSTEMOWYCH GLEBY}

Streszczenie. Wycena Usług Ekosystemowych jest ważnym narzędziem dialogu w procesie podejmowania decyzji i podkreślania zależności społeczeństwa od biosfery dla dobrej jakości życia. Gleba jest głównym źródłem usług ekosystemowych, takich jak produkcja żywności i regulacja klimatu, ale metodyczne alternatywy wyceny usług ekosystemowych gleby pozostają słabo zbadane. Celem niniejszej pracy jest przedstawienie aspektów metodologicznych wyceny usług ekosystemowych, ze szczególnym uwzględnieniem usług glebowych w kontekście rolniczym. W artykule przedstawiono ramy specyficzne dla usług ekosystemowych gleby. Na wstępie pokrótce zaprezentowano przegląd usług ekosystemowych. Następnie omówiono główne koncepcje wyceny usług ekosystemowych, ze szczególnym uwzględnieniem wyceny ekonomicznej. W kolejnej części przedstawiono studium przypadku oceniające usługi ekosystemowe gleby w kontekście rolnictwa oraz zaproponowano metodologię wyceny korzyści płynących z ekosystemu glebowego. W podsumowaniu stwierdzono, że taka wycena reprezentuje najnowszy trend w gleboznawstwie, gdzie zasoby glebowe traktuje się w szerszym kontekście wpływu na dobrostan człowieka. Ponadto, niniejsze opracowanie podkreśla znaczenie badań, projektów i instytucji z z właściwym zrozumieniem definicji koncepcji usług ekosystemowych gleby (SES- z angielskiego: soil ecosystem services) i innych pokrewnych pojęć, takich jak właściwości, procesy i funkcje gleby.

Słowa kluczowe: systemy rolnicze, biowęgiel, metody, framework 